\title{
Survival of micro hedge funds
}

\section{Greg N. Gregoriou}

State University of New York (Plattsburgh), 101 Broad Street, Plattsburgh, NY 12901, USA.

Tel: (518) 564 4202, Fax: (518) 564 4215;

E-mail: greg.gregoriou@plattsburgh.edu

Received (in revised form): 14th March, 2006

Greg N. Gregoriou is Associate Professor of Finance and Coordinator of Faculty Research at State University of New York (Plattsburgh) and Hedge Fund Editor for Derivatives Use, Trading and Regulation.

\section{Practical applications}

Survival analysis can assist funds of hedge fund (FOF) managers, institutional investors, pension funds and endowment funds to identify hedge fund classifications with the longest and shortest survival lifetimes. The results will help FOF managers to construct portfolios of hedge funds and help them avoid funds that die prematurely.

\section{Abstract}

This paper investigates the survival times of micro hedge funds during the 1994-2003 period. Each classification's mean survival time is estimated, in increments of $\$ 5$ million and with an upper boundary at less than $\$ 50$ million. Consistent with previous findings in the literature, smaller funds less than $\$ 50$ million tend to have shorter survival times. Taking this one step further, the author believes that the smallest hedge funds will have the highest mortality rates. Derivatives Use, Trading \& Regulation (2006) 12, 209-218. doi:10.1057/palgrave.dutr.1850041

Keywords: survival; micro hedge funds; median survival; Kaplan-Meir; hazard rates

\section{INTRODUCTION}

The Securities and Exchange Commission (SEC) 'Hedge Fund Rule', which was recently invalidated by the US Court of Appeals in June 2006, treated micro hedge funds (with less than $\$ 25$ million under management) differently from other hedge funds. ${ }^{1}$ That rule left micro hedge funds largely unregulated. However, the number of live and dead hedge funds with less than $\$ 25$ million under management represents a significant portion of an investor's money totalling approximately $\$ 95$ and $\$ 65$ billion, respectively. This may warrant further investigation on the part of the SEC and other regulators and may motivate any future regulation of hedge funds to cover micro hedge funds with assets less than $\$ 25$ million as well as larger hedge funds.

Small hedge funds can typically build enough critical mass and continue to increase their asset base, but usually have a tendency to underperform large funds because of the high expense ratios that often dig into their returns. ${ }^{2}$ 
Ammann and Moerth ${ }^{2}$ find a negative relationship between size and performance, and between size and volatility.

When investing in hedge funds, institutional investors, pension funds and endowment funds typically require 3-5-year track records before allocating any assets to alternative investment vehicles. Many investors, however, stay away from investing in small funds and tend to prefer large funds because of the illusion of safety in numbers. Furthermore, small hedge funds that fail to attract a large amount of capital in order to meet operating expenses on a day-to-day basis may face a quick death and may have the shortest survival lifetimes. Nonetheless, there are some micro hedge funds in certain classifications that tend to do well.

Previous studies have examined the survival of hedge funds and funds of hedge funds (FOFs) in aggregate and by classification, but all failed to address the survival lifetimes of hedge funds with less than $\$ 50$ million under management. ${ }^{3,4}$ This raises the question of whether micro hedge funds with less than $\$ 50$ million under management have different survival times when increments of $\$ 5$ million are examined in depth. Eventually, some micro hedge funds do reach their optimal targeted operating size and continue to gather momentum, but of the 692 hedge funds in the $\$ 0-\$ 5$ million category, 49.4 per cent are considered defunct. How can investors select which micro hedge funds will survive the longest? Do funds with assets less than $\$ 25$ million have shorter survival times than funds with assets between $\$ 25$ million and $\$ 50$ million (using $\$ 5$ million increments)?

The number of live and micro hedge funds with less than $\$ 50$ million under management has grown at an exponential rate since the mid 1990s, according to the Hedge Fund Research
(HFR) database. What is the life expectancy of micro hedge funds by assets under management for each classification? Do the smallest hedge funds have the shortest survival times?

Survival analysis can help inform investors identify which classifications may be appropriate for a portfolio, assuming these investors prefer micro hedge funds. While Gregoriou ${ }^{3}$ examines hedge funds in aggregate (less than $\$ 50$ million), this study goes one step further by extracting the smaller funds and estimating the mean survival times in $\$ 5$ million increments between the $\$ 0$ and $\$ 50$ million range. This is particularly useful for investors wanting to select micro hedge fund managers who may become the stars of tomorrow.

\section{SURVIVAL ANALYSIS IN BRIEF}

Survival analysis is mainly concerned with statistical techniques to predict the time to an event (notably death), known as the 'survival time'. Survival analysis provides a thorough approach for estimating the probability of a hedge fund dying as a function of predictor variables. Furthermore, the defunct label in the database equates with having stopped reporting owing not only to operational failure or shutdown but also to diverse reasons such as a streak of poor performances, merging with another fund or the unwillingness to attract new capital because of capacity constraints. As pointed out by Fung and Hsieh, ${ }^{5}$ numerous funds are not defunct and have very good returns. Survival analysis can help understand how the features of hedge funds affect their lifetime and thus fund performance in general. Institutional investors, endowments and pension funds can only but benefit in this regard.

The important feature of all methods of survival analysis is that they allow for censored 
lifetimes, that is, for hedge funds that are still alive at the end of the observation period. When all hedge funds are observed until failure, there is no censoring and traditional models, such as OLS regression, can be used to investigate how lifetimes depend on a number of explanatory variables. Note that in survival studies, which are longitudinal in nature, funds are continuously followed over an investigation period. The goal of this study is to estimate how long micro hedge funds are likely to survive, while allowing for censoring.

\section{LITERATURE REVIEW}

We revisit the literature review of Gregoriou ${ }^{3,4}$ and add the new developments in the literature. Baquero et al. ${ }^{6}$ find that hedge fund style is a meaningful factor in explaining survival, and that large hedge funds survive longer than smaller ones. Brown et al. ${ }^{7}$ find that there is a higher dying rate for young funds, a finding further confirmed by Amin and Kat. ${ }^{8}$ Brooks and $\mathrm{Kat}^{9}$ find that approximately 30 per cent of new hedge funds do not make it past 36 months, due to poor performance. Amin and $\mathrm{Kat}^{8}$ also find that 40 per cent of hedge funds do not make it to their fifth year. Howell ${ }^{10}$ finds that the probability of new hedge funds failing in their first year is 7.4 per cent and the probability increases to 20.3 per cent in their second year. Another finding of Amin and $\mathrm{Kat}^{8}$ is that new funds with a small amount of assets under management are likely to take on additional risk to enhance their returns and solicit investors. This, they conclude, may help explain their premature death.

Poor-performing young funds drop out of databases at a faster rate than older funds according to a recent study examining
3,477 live and dead funds during the period 1980-2000. ${ }^{11}$ Boyson $^{12}$ reaches the same conclusion with the TASS database. She observes that hedge fund size has a strong effect on survival, in particular, that smaller hedge funds die faster than large ones over the 1994-2000 period.

Although the survival lifetimes of hedge funds seem to vary across the above-mentioned studies, one must understand that they also differ among classifications. Recently, Byron Wien in Huemer $^{13}$ argued that small hedge funds perform better than large hedge funds. Using the Zurich Capital Markets (ZCM) database during the 1990-2003 period, Gregoriou ${ }^{3}$ finds the opposite. In particular, he finds that 83 per cent of small funds (less than $\$ 50$ million in assets) are defunct, whereas only 17 per cent of large funds (more than $\$ 50$ million) are defunct. In addition, Gregoriou, ${ }^{3}$ using 1,503 live funds and 1,273 dead funds, finds that hedge funds with less than $\$ 16$ million have shorter survival times than funds with greater than $\$ 16$ million under management. Interestingly enough, Gregoriou ${ }^{3}$ estimates the median survival lifetimes for hedge funds in aggregate at 5.5 years and concludes that large funds, on average, survive longer, have higher returns, possess lower leverage and have low minimum purchase requirements. Of the 10 classifications examined, funds of hedge funds have the longest median survival time, estimated at 7.5 years. A subsequent study by the SEC, ${ }^{14}$ using the Van Hedge, database also finds the median survival for hedge funds to be 5.5 years.

The number of live micro hedge funds with less than $\$ 50$ million under management is greater than the number of funds with average assets under management more than $\$ 50$ million according to the HFR database. For funds with 
Table 1: Survival of Size by Average Millions Managed

\begin{tabular}{|c|c|c|c|c|c|}
\hline $\begin{array}{l}\text { Frequency } \\
\text { (\$millions) }\end{array}$ & Live & Dead & Total & $\begin{array}{l}\text { Total ending } \\
\text { assets under } \\
\text { management } \\
\text { (\$billion) (live) }\end{array}$ & $\begin{array}{l}\text { Total ending } \\
\text { assets under } \\
\text { management } \\
\text { (\$billion) (dead) }\end{array}$ \\
\hline $0-5$ & 350 & 342 & 692 & $1,405.41$ & 840.68 \\
\hline $5-10$ & 243 & 181 & 424 & $3,362.32$ & $1,282.72$ \\
\hline $10-15$ & 223 & 101 & 324 & $4,927.39$ & $1,306.37$ \\
\hline $15-20$ & 172 & 84 & 256 & $5,361.92$ & $1,460.86$ \\
\hline $20-25$ & 149 & 58 & 207 & $6,224.84$ & $1,240.24$ \\
\hline $25-30$ & 131 & 44 & 175 & $6,617.86$ & $1,704.22$ \\
\hline $30-35$ & 95 & 49 & 144 & $5,240.19$ & $1,854.17$ \\
\hline $35-40$ & 94 & 28 & 122 & $7,105.79$ & $1,021.66$ \\
\hline $40-45$ & 72 & 29 & 101 & $5,485.66$ & $2,426.29$ \\
\hline $45-50$ & 59 & 24 & 83 & $4,986.20$ & $1,009.91$ \\
\hline$>50$ & 766 & 263 & 1,029 & $305,844.51$ & $64,477.62$ \\
\hline Total & 2,354 & 1,203 & 3,557 & $356,562.09$ & $78,624.74$ \\
\hline
\end{tabular}

less than $\$ 10$ million under management, the compliance cost will be approximately between $\$ 25,000$ and $\$ 50,000$. $^{1}$ One would assume that the SEC would have had a cost benefit for not forcing hedge funds (with onshore advisors) with less than $\$ 25$ million to register with the Commission.

\section{DATA}

We examined 2,275 live and 1,145 dead funds from 1st January, 1994 to 31st December, 2003 using the HFR database. The data consist of returns net monthly and management and performance fees. The funds enter the HFR database and remain alive until they stop to report their performance number for three consecutive months, at which time they are considered dead. They can, however, re-enter the database at a certain point and backfill their unreported returns. For our purposes, we restrict our sample to funds less than $\$ 50$ million and the sample size is reduced to 1,588 live and 940 dead funds (Table 1).

The survival times of hedge funds at the end of the ten-year period are right censored, since unlike the dead funds, their lifetimes are not exactly known, only to occur after the ten-year period. The median survival time in each classification is estimated. This can help investors to identify the styles that survive the longest and the ones with the greatest mortality rates.

\section{METHODOLOGY}

The Kaplan-Meier estimator (KM) is used to estimate the survival function, $S(t)$, and the median survival time, defined as the age $t_{0}$ at which one half of the hedge funds die. Hence, 
$S\left(t_{0}\right)=0.5$ so that one-half of the hedge funds die before age $t_{0}$ and the other half lives longer than age $t_{0}$. We use the actuarial estimator to estimate the hazard function and produce hazard plots. The KM and actuarial estimators are similar, except that the KM uses exact death times while the actuarial estimator uses death times grouped into intervals. In this study, we use groups of one year. Both estimators of $S(t)$ are non-parametric because a density function for lifetimes, $f(t)$, need not be specified. In calculating the KM estimator, the data are partitioned into time intervals, usually defined at each failure point marked by $d_{j}$ deaths. If $r_{j}$ denotes the number of funds alive immediately preceding the $j$ th failure, then $1-d_{j} / r_{j}$ represents the (conditional) probability of survival within the interval ending at the $j$ th failure time, given that the fund was alive at the beginning of the interval. Multiplying over all intervals yields the $\mathrm{KM}$ estimator, which is the (unconditional) probability of survival up to time $t$ :

$$
S(t)=\prod_{j=1}^{m}\left(1-\frac{d_{j}}{r_{j}}\right)
$$

for $t$ in the interval $\left(t_{m}, t_{m+1}\right)$,

where $m$ represents the number of failures observed up to time $t$. Once the KM estimate of the survival function, $\hat{S}(t)$, is obtained, the mean survival time $\bar{t}$ is estimated by integrating $\hat{S}(t)$ over $t>0$, so that $\bar{t}=\int_{0}^{\infty} S(u) \mathrm{d} u$. The hazard function is the probability of mortality at each point in time and is plotted for three cases. For further discussion on the hazard function, see Gregoriou. ${ }^{3}$

\section{EMPIRICAL RESULTS}

The results in Table 1 indicate that the smallest hedge funds in the $\$ 0-\$ 5$ million category have the largest percentage of dead funds (49.42\%). As we progress to the next category ( $\$ 5$ million $-\$ 10$ million), the percentage of dead funds tends to decrease $(42.69 \%)$. This pattern repeats itself up the asset categories, with the $\$ 35$ million- $\$ 40$ million range having the smallest percentage of dead funds.

Of the 1,203 dead hedge funds, 766 funds were in the less than $\$ 25$ million category representing 63.67 per cent. In terms of assets under management of the 2,354 live funds totalling $\$ 356,562$ billion, 1,137 funds had assets under management of $\$ 21,281.88$ billion (almost 6 per cent) in the less than $\$ 25$ million category. The total assets under management of the dead funds amounted to $\$ 78,624.00$ billion; however, in the less than $\$ 25$ million category the total assets of dead funds amounted to $\$ 6,130.87$ billion (almost 8 per cent). It is clear that investors should stay away from small funds with less than $\$ 25$ million under management and another reason why any future regulation by the SEC should cover hedge funds under $\$ 25$

million. Table 1 further displays the ending total assets under management.

Table 2 examines the median survival lifetimes (half-life) along with the 25 and 75 per cent quartile survival lifetimes. Funds with average assets between $\$ 25$ million and $\$ 50$ million have a median survival lifetime of 8.00 years, while it is almost 5.00 years for funds between $\$ 0$ and $\$ 25$ million. Small funds ( $\$ 0-\$ 25$ million) have a mean survival time of 5.46 years, while the larger funds (\$25 million-\$50 million) have a slightly higher mean survival time of 7.16 years. The survival times of funds in the $\$ 0$ to $\$ 25$ million category at the 75 per cent quartile were underestimated because the largest observation was censored and the estimation was restricted to the largest event time. Confidence intervals in 
Table 2: 25, 50 and 75\% Survival Lifetimes

Quartile estimates

\begin{tabular}{|c|c|c|}
\hline Per cent & Point estimate in years & $\begin{array}{l}\text { 95\% confidence interval } \\
\text { [lower, upper) }\end{array}$ \\
\hline
\end{tabular}

$\$ 0-\$ 25 m$

75

50

25

\subsection{3}

2.5024

Mean survival time in years

5.46

$\$ 25 m-\$ 50 m$

75

50

25
10.0780

8.0000

4.4189

Mean survival time in years

7.16
$[-,-)$

$[4.5859,5.5797)$

$[2.3354,2.6667)$
Table 2 are narrow, signifying accuracy in the estimated survival times; however, some intervals do not have upper and/or lower limits which is due to heavy censoring in the data.

Table 3 displays the mean survival times of all classifications and in incremental classes of $\$ 5$ million increments. The only classification in the \$0-\$5 million category that has the highest mean survival time is fixed income with 4.75 years, whereas short seller classification has the shortest survival time with 1.33 years. In the $\$ 5$ million$\$ 10$ million category, the equity hedge classification comes out ahead and has the longest survival time (5.08 years). Dashes indicate that there are not sufficient funds heavy censoring in each category. An interesting finding is that the fund of funds classification in the $\$ 20$ million- $\$ 25$ million category has the greatest mean survival time of 7.70 years.
One may assume that this may be the optimal size ( $\$ 20$ million- $\$ 25$ million) for a micro fund of funds. Table 3 further displays that the average mean survival times ( 1.33 years) per dollars under management is the lowest in the $\$ 0-\$ 5$ million category. Investors may be well advised not to invest in micro hedge funds with less than $\$ 25$ million under management. The results in Table 3 confirm that the mean survival lifetimes trend generally increases and peaks at the $\$ 25-\$ 30$ million (5.40 years) and then drops slightly only to increase again in the greater than $\$ 50$ million category (5.23 years).

Table 4 displays the number of live and dead funds by classification and assets under management. The table identifies that the Convertible Arbitrage category has the smallest percentage of dead funds (17.48 per cent) while the Equity 


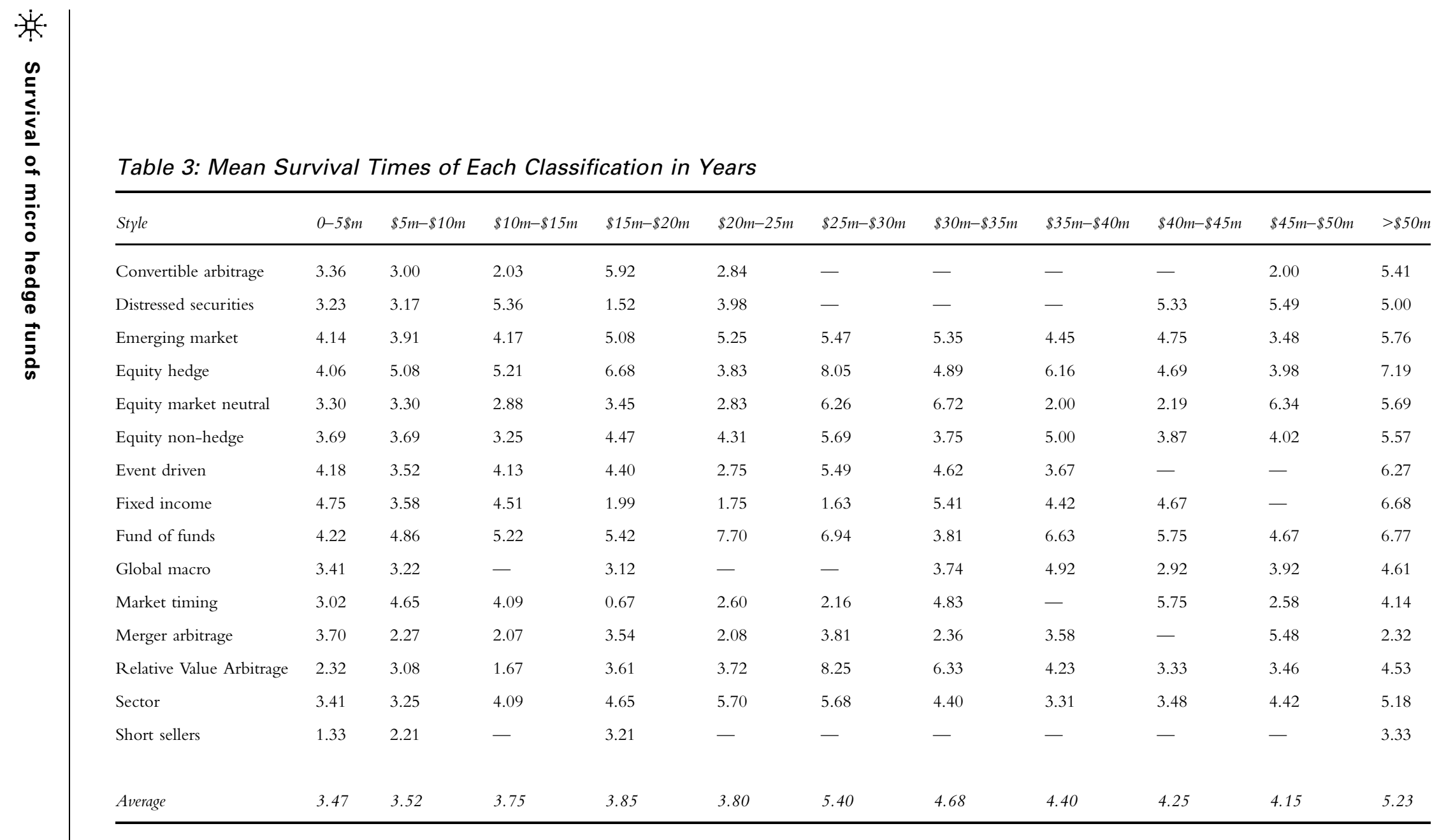




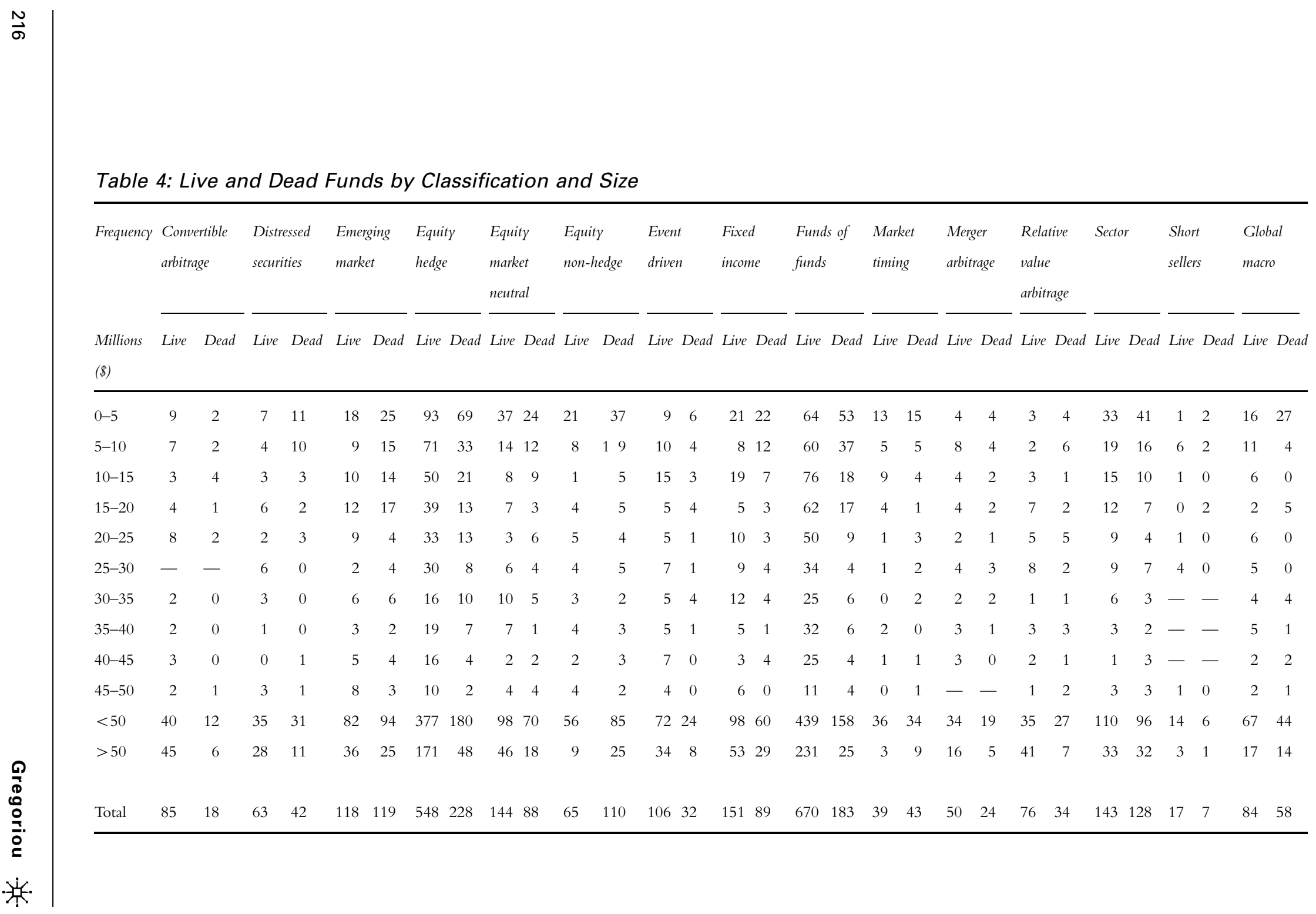




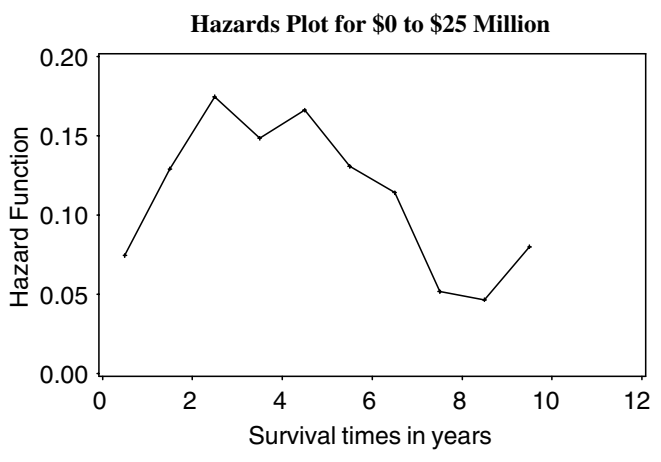

Figure 1: Hazards plot for $\$ 0-\$ 25$ million

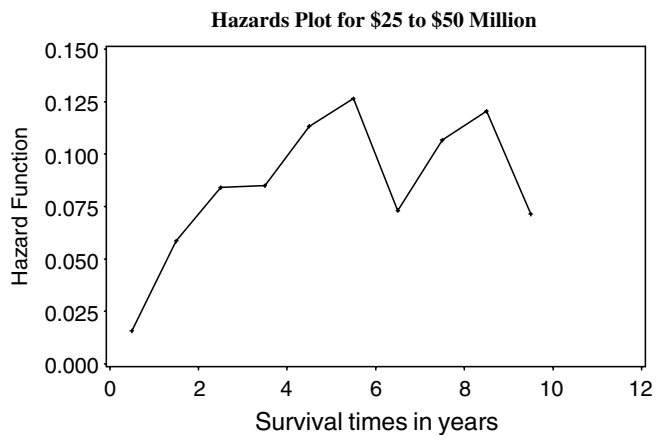

Figure 2: Hazards plot for $\$ 25$ million- $\$ 50$ million

\section{Non-hedge category has the largest $(62.86$ per cent).}

In Figure 1 (\$0-\$25 million), the plot of the hazard function does not appear to be flat, indicating a non-constant hazard and suggesting that new funds struggle during the first two years of operation, but then establish themselves so that their risk of failure (the hazard) is small for new and old funds (greater than seven years).

The hazard, however, increases after Year 8. At its peak the hazard function is approximately 0.175 per cent per month or 2.10 per cent annualised.

In Figure 2 ( $\$ 25$ million- $\$ 50$ million), the hazard plot suggests that new funds struggle

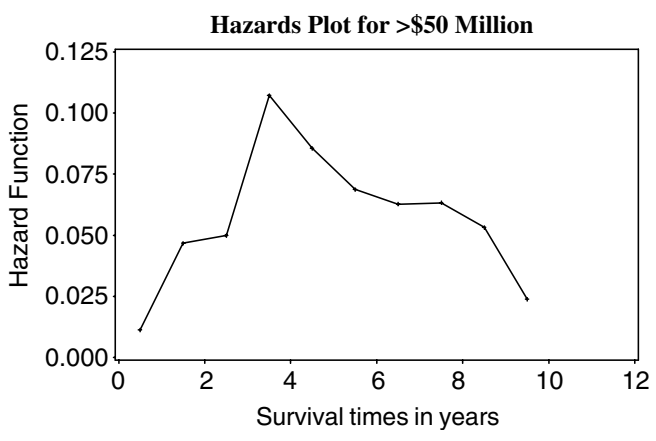

Figure 3: Hazards plot for $>\$ 50$ million

during the first five years, but then their risk of failure in Year 5 decreases until Year 6 only to increase again during the sixth and seventh years and finally to have the hazard decreases again after Year 8. At its peak the hazard function is approximately 0.135 per cent per month or 1.63 per cent annualised. In Figure 3 (greater than $\$ 50$ million), however, new funds struggle until the fourth year only to have the hazard decrease from approximately Year 4 onwards.

\section{CONCLUSION}

This paper investigates the survival lifetimes of micro hedge funds during the 1994-2003 period. The general conclusion is that investors should, on average, avoid hedge funds with less than $\$ 25$ million under management. With the large number of live and dead funds in the less than $\$ 25$ million category, any further regulation of hedge funds may need to take into account the excessive number of deaths.

\section{Acknowledgments}

The author thanks Fabrice Douglas Rouah and Paul Ali for comments and suggestions as well as Josh Rosenberg at HFR for providing the data. Selected parts of this paper have been reproduced from previous articles of this author 
that have appeared in the Journal of Wealth Management, Journal of Asset Management and the Journal of Derivatives Accounting.

\section{References and Notes}

1 Securities and Exchange Commission (2004) 'Registration under the Advisers Act of Certain Hedge Fund Advisers' 69 Fed. Reg. 72,054. This rule was invalidated by the US Court of Appeals for the District of Columbia: Goldstein v SEC (23rd June, 2006).

2 Ammann, M. and Moerth, P. (2005) 'Impact of Fund Size on Hedge Fund Performance', Journal of Asset Management, Vol. 6, No. 3, pp. 219-238.

3 Gregoriou, G.N. (2002) 'Hedge Fund Survival Lifetimes', Journal of Asset Management, Vol. 2, No. 3, pp. 237-252.

4 Gregoriou, G.N. (2003) 'The Mortality of Funds of Hedge Funds', Journal of Wealth Management, Vol. 6, No. 1 pp. $42-53$.

5 Fung, W. and Hsieh, D.A. (2002) 'Benchmarks of Hedge Fund Performance: Information Content and Measurement Biases', Financial Analyst Journal, Vol. 58, No. 1, pp. 22-34.

6 Baquero, H., ter Horst, J. and Verbeek, M. (2002) 'Survival, Look-Ahead Bias and the Performance of Hedge Funds'Working Paper, Erasmus University, Rotterdam, Holland and Tilburg University, Tilburg, Holland.
7 Brown, S.J., Goetzmann, W.N. and Park, J. (2001) 'Careers and Survival: Competition and Risk in the Hedge Fund and CTA Industry', The Journal of Finance, Vol. 56, No. 5, pp. 1869-1886.

8 Amin, G.S. and Kat, H.M. (2002) 'Welcome to the Dark Side: Hedge Fund Attrition and Survivorship Bias Over the Period 1994-2001', Working Paper, University of Reading, ISMA Centre.

9 Brooks, C. and Kat, H.M. (2001) 'The Statistical Properties of Hedge Fund Index Returns and their Implications for Investors', Working Paper, University of Reading, ISMA Centre, Reading, UK.

10 Howell, M.J. (2001) 'Fund Age and Performance', Journal of Alternative Investments, Vol. 4, No. 2, pp. 57-60.

11 Jen, P., Heasman, C. and Boyatt, K. (2001) 'Alternative Asset Strategies: Early Performance in Hedge Fund Managers', Lazard Asset Management, New York, NY.

12 Boyson, N. (2002) 'How Are Hedge Fund Manager Characteristics Related to Performance, Volatility and Survival', Working Paper, Ohio State University, Columbus, $\mathrm{OH}$.

13 Huemer, J. (2002) 'Trying to Sort the Myth from Reality', Financial Times, 14th May.

14 SEC (2003) Implications of Growth of Hedge Funds. Staff Report to the United States Securities and Exchange Commission. http://www.sec.gov/news/ studies/hedgefunds0903.pdf. 